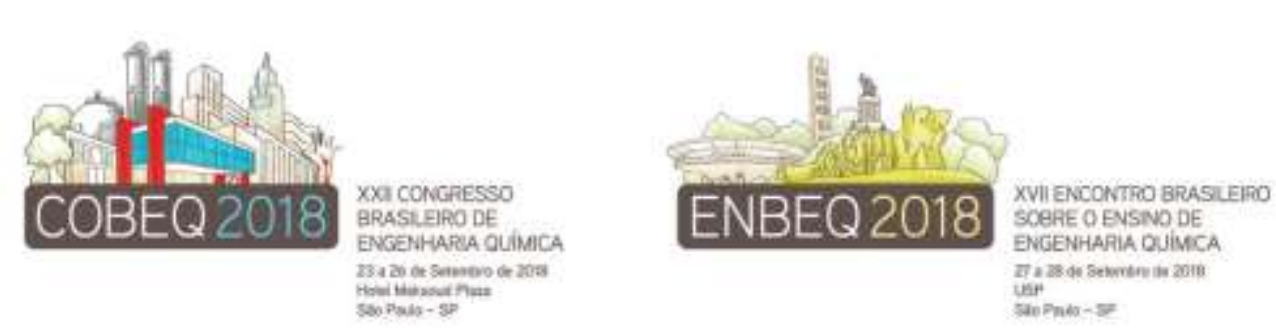

\title{
EXTRACTION AND CHARACTERIZATION OF LIGNIN FROM CASHEW APPLE BAGASSE AIMING FUTURE APPLICATION WITHIN NEW MATERIALS
}

\author{
SERPA, J. de F. ${ }^{1}$, MATIAS, G. A. B. ${ }^{1}$, SILVA, J. S. ${ }^{1}$, COSTA, V. M. da ${ }^{2}$, MICOLI, L. ${ }^{3}$, \\ MACEDO, A. C. ${ }^{1}$ e ROCHA, M. V. P. ${ }^{1}$ \\ ${ }^{1}$ Universidade Federal do Ceará, Chemical Engineering Department, Campus do Pici, Bloco \\ 709, 60455 - 760 Fortaleza - CE, Brazil. \\ ${ }^{2}$ Universidade Federal do Ceará, Chemical Department, Campus do Pici, Bloco 940, 60455 - \\ 760 Fortaleza - CE, Brazil. \\ ${ }^{3}$ Università degli Studi di Napoli Federico II, Department of Chemical, Materials and \\ Production Engineering, Ple Tecchio 80, 80125, Naples, Italy \\ E-mails: serpajuli5@hotmail.com; gabmatias2@gmail.com; jouciane@gmail.com; \\ vmdcosta@gmail.com; luca.micoli@unina.it; acasimiro@gmail.com; \\ valpontericha@yahoo.com.br
}

\begin{abstract}
The lignins resulting of pretreatment from cashew apple bagasse with alkaline hydrogen peroxide and acid/alkali were extracted and characterized. The extracted lignin's showed similar characteristics to those mentioned in the literature, becoming a product of great potential raw for production of different materials. The application of the obtained lignins as material shows a positive impact for the economy.
\end{abstract}

\section{INTRODUCTION}

Cashew apple is a pseudofruit from the Northeastern region of Brazil with an outstanding economic role due to the cashew nut exportation. According to the Food and Agriculture Organization of the United Nations the world demand for cashew production grows annually. More than 110 thousand tons of this fruit are exported per year, generating an income of 2 billion dollars (FAO 2006). The industry of juice from cashew apple produce $15 \%(\mathrm{w} / \mathrm{w})$ of bagasse, representing one of the major waste from the Brazilian agribusiness (Correia et al., 2013; Rocha et al., 2014; Reis et al., 2017). In addition, the composition of cashew apple bagasse (CAB) points the raw material as an alternative and inexpensive lignocellulosic material for the production of ethanol. However, the cashew apple bagasse structure is highly recalcitrant to microbial and enzymatic biotransformation, limiting its use and making its conversion into value-added products not economically feasible. So, the pretreatments are needed to disrupt the recalcitrant structures of the lignocellulosic material to increase the digestibility of the material prior to the conversion into ethanol (Rocha et al., 2011). During the pretreatment of cashew apple bagasse, lignin is discarded and becomes a co-product. Though, it is a potential raw for production of different materials.

Lignin, which consists of $10-35 \%$ of the lignocellulosic biomass, is the second most abundant natural polymer and in spite of this fact it is a vastly under-utilized material. It is insoluble in water and stable in nature and acts as the "glue" that binds cellulose and 


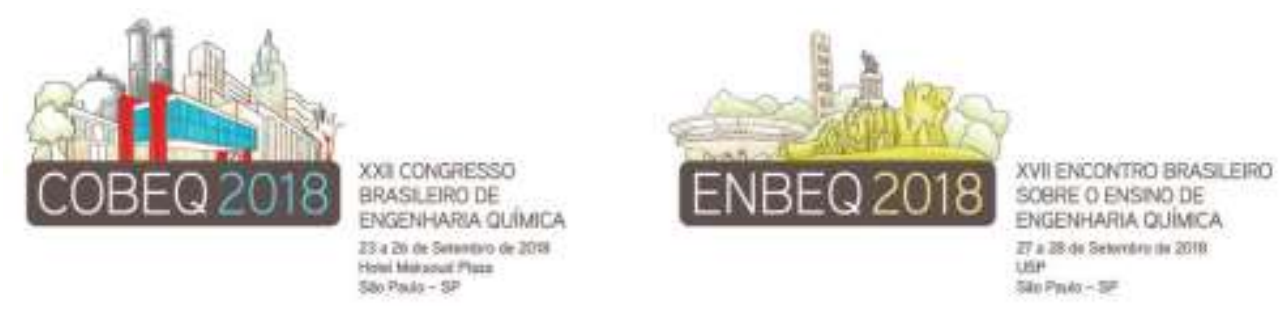

hemicellulose. Its structure is three-dimensional and consists of three phenol groups which include: p-hydroxyphenyl (H), guaiacyl (G) and syringyl (S) (Fengel, 1989). The lignin extracted during pretreatment has been a source of study in several works because it is a fibrous and quite resistant material (Li et al., 2015; Mohan et al., 2015). However, only an insignificant part is used in specialty products, the rest serves as fuel for thermal energy generation. Currently, a wide variety of chemicals can be produced in a sustainable way from the aromatic structures of lignin (Silva et al., 2013). Due to its high molecular weight, lignin can be used to produce carbon fibers, polymer modifiers, adhesives and resins (Frollini and Castellan, 2012). In addition, lignin has antioxidant activity, because of the presence of phenolic groups and benzylic hydrogens.

There are different types of lignin regarding the biomass resource they are obtained, and also depending on the isolation protocol. Then, this research aimed to extract and characterize lignin from cashew apple bagasse, an abundant agro-industrial residue in various countries, in order to use the lignin as new materials.

\section{APPROACH}

The raw material (cashew apple bagasse, scientific name Anacardim occidentale L.) used in this study was kindly donated by the Jandaia Industry of Juice (Ceará, Brazil). The $\mathrm{CAB}$ was washed, dried at $60{ }^{\circ} \mathrm{C}$ for $24 \mathrm{~h}$ and it milled, in order to obtain particles with size between 0.25 and $0.84 \mathrm{~mm}$. The milled $\mathrm{CAB}$ was pretreated by alkaline hydrogen peroxide (AHP) and acid/alkali according to the best conditions obtained in the study of Correia et al. (2013) and Rocha et al. (2009), respectively. A solids concentration of 5\% (w/v) CAB, was slurred in hydrogen peroxide $\mathrm{H}_{2} \mathrm{O}_{2}(4.3 \% \mathrm{v} / \mathrm{v})$ with the $\mathrm{H}_{2} \mathrm{O}_{2}$ solution adjusted to $\mathrm{pH} 11.5$ using 6 mol. $\mathrm{L}^{-1} \mathrm{NaOH}$. The pretreatment was conducted in an orbital shaker (Tecnal - TE 422, SP, Brazil) at $35^{\circ} \mathrm{C}$ for $6 \mathrm{~h}$ and $250 \mathrm{rpm}$. The acid pretreatment was carried out at 121 ${ }^{\circ} \mathrm{C}$ for 15 min using $\mathrm{H}_{2} \mathrm{SO}_{4} 0.6 \mathrm{M}$ and $30 \% \mathrm{w} / \mathrm{v} \mathrm{CAB}$, followed by alkali treatment, waterinsoluble solids from the acid pretreatment were impregnated with $4 \% \mathrm{w} / \mathrm{v} \mathrm{NaOH}$ at $121{ }^{\circ} \mathrm{C}$ for $30 \mathrm{~min}$ in autoclave. After pretreatment step, the liquors were separated from the solid fraction by filtration. Then, these liquors were reserved for the precipitation and recovery of lignin. Lignin present in the liquors obtained of the pretreatment was recovered by precipitation with acidification at $\mathrm{pH} 2$ using $50 \% \mathrm{v} / \mathrm{v} \mathrm{H}_{2} \mathrm{SO}_{4}$. The mass of precipitated lignin was calculated in dry mass basis. The lignin resulting were characterized by the methods of elemental composition analysis, immediate analysis, FTIR and DSC.

\section{RESULTS}

Of the liquids fractions obtained after pretreatments of cashew apple bagasse- with AHP and acid-alkali, were extracted a mass of lignin of $12.69 \mathrm{~g}$ and $16.70 \mathrm{~g}$, respectively, for each $100 \mathrm{~g}$ of CAB. Immediate analysis of the extracted lignin with AHP was $5.71 \%$ of moisture, $9.67 \%$ of fixed carbon, $78.64 \%$ of volatiles and $5.96 \%$ of ash and for lignin obtained of the acid-alkali pretreament was $9.43 \%$ of moisture, $28.15 \%$ of fixed carbon, $57.60 \%$ of volatiles and $4.82 \%$ of ash.

Contents of carbon, hydrogen and nitrogen in extracted lignin with AHP were 51.5\%, $7.34 \%$ and $6.66 \%$, respectively, and contents of carbon, hydrogen and nitrogen in the acidalkali extracted lignin samples was $54.46 \%, 6.27 \%$ and $2.16 \%$, respectively. The values for 


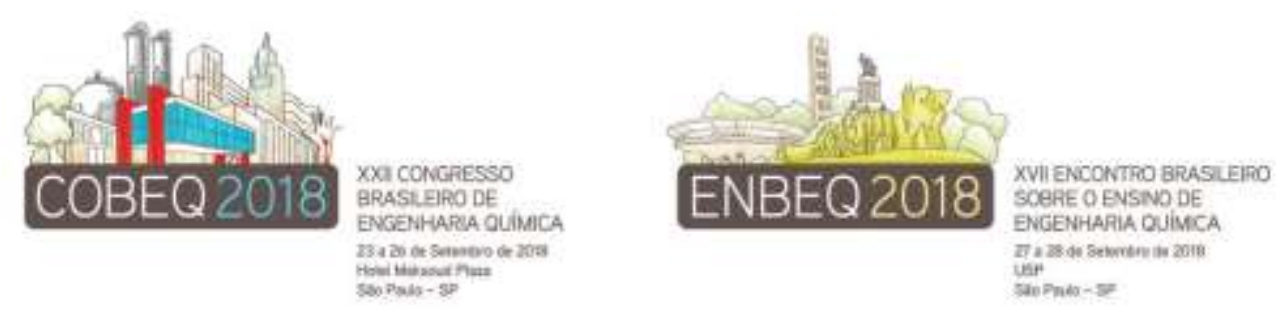

elemental analysis found in the literature show variations, possibly caused by the composition of the lignin source material as well as the extraction process. Konduri et al. (2015) studied the characterization of hardwood lignin and obtained the following contents: carbon $64.76 \%$, hydrogen $5.78 \%$ and nitrogen $0.03 \%$.

The FTIR spectra of the lignins obtained during the pretreatment from CAB using AHP (Figure 1-A) and during the acid/alkali pretreatment (Figure 1-B) showed a successful fractionation, since the bands are well defined in specific wavelengths. The lignins obtained in the present study may be considered free of carbohydrates. According to Lopes et al. (2013), since no characteristic bands at 897,1046 and $1080 \mathrm{~cm}^{-1}$ were observed, lignin did not present carbohydrates in its structure. The spectrum obtained exhibited absorption bands typical of lignin and similar to those obtained by LI et al. (2015). The aforementioned authors concluded in their spectra that bands with maximum absorbance at $3430 \mathrm{~cm}^{-1}$ represent stretching of OH groups, $2962 \mathrm{~cm}^{-1}$ stretching $\mathrm{CH}$ of methyl or methylene groups, $2854 \mathrm{~cm}^{-1}$ $\mathrm{CH}$-vibration of methyl methoxy groups, $1737 \mathrm{~cm}^{-1}$ stretch $\mathrm{C}=\mathrm{O}, 1550 \mathrm{~cm}^{-1}$ vibration of aromatic rings.
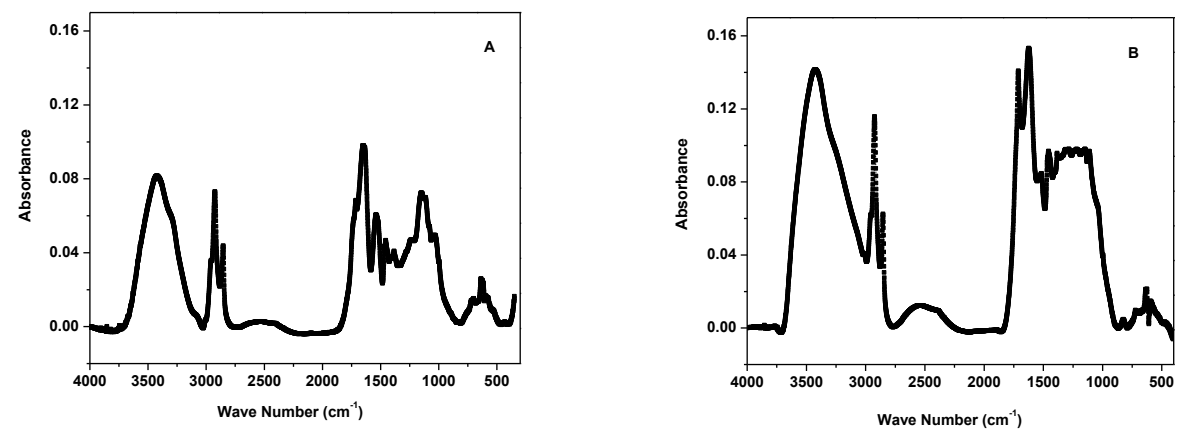

Figure 1: (A) The FTIR spectrum of the lignin obtained during the pretreatment of cashew apple bagasse using alkaline peroxide hydrogen $\left(4.3 \% \mathrm{v} / \mathrm{v}, \mathrm{pH} 11.5,5 \% \mathrm{w} / \mathrm{v}\right.$ CAB, $35^{\circ} \mathrm{C}, 250 \mathrm{rpm}$ for $\left.6 \mathrm{~h}\right)$. (B) The FTIR spectrum of the lignin obtained during the pretreatment of cashew apple bagasse using acid/alkali ( $\mathrm{pH} 13.5)$.

Thermal stability studies of the lignins extracted from alkaline hydrogen peroxide and acid-alkali pretreatments were carried out through Differential Scanning Calorim

etry (DSC). The results of the DSC analysis show the variation of the curve in the degradation process. For two lignins the DSC curves were initiated with endothermic regions due to the heat required for the evaporation of moisture before the heat flow from endothermic to exothermic, being up to $600{ }^{\circ} \mathrm{C}$ for lignin from AHP, and up to $450{ }^{\circ} \mathrm{C}$ for lignin from acid-alkali pretreatment, that occur a change between $450{ }^{\circ} \mathrm{C}$ and $550{ }^{\circ} \mathrm{C}$ where shortly after the thermal degradation process restart. The melting enthalpies change the degradation process of the samples too, which matches the values in literature (Mousavioun et al., 2013). Lignin sample takes place the melting change between $600{ }^{\circ} \mathrm{C}$ and $700{ }^{\circ} \mathrm{C}$ for $\mathrm{AHP}$ pretreatment.

\section{CONCLUSIONS}

Lignins extracted from cashew apple bagasse by pretreatment with alkaline hydrogen peroxide and acid/alkali show characteristics similar to those mentioned in the literature according to the characterization processes. Then, applications are emergent for these lignins 


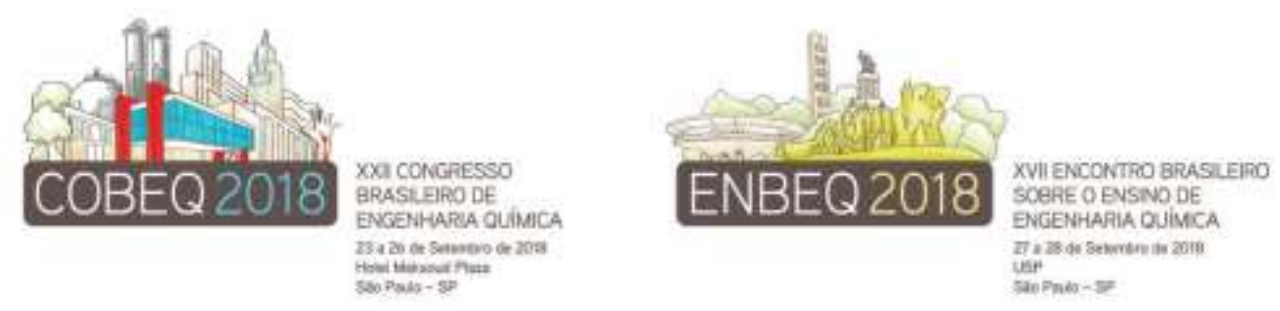

in diverse areas, principally as sustainable alternatives to non-renewable products, such adsorbent, support for enzyme immobilization, and phenolic and epoxy resins.

\section{REFERENCES}

CORREIA, J. A. C., Estudo do pré-tratamento do bagaço de caju com peróxido alcalino para a produção de etanol Tese (Master in Chemical Engineering) - Centro de Tecnologia - Universidade Federal do Ceará. Fortaleza-CE, 2013.

FENGEL, D.; Wegener, G. Wood: Chemistry, Ultrastructure, Reactions, Walter De Gruyter. Berlim., 1989.

FROLLINI, E.; castellan, A. Phenolic resins and composites. In: Encyclopedia of Composites, 2nd ed. John Wiley \& Sons, Hoboken, New Jersey, p. 2059-2068, 2012.

KONDURI, M. K.; Kong, F.; Fatehi, P. Production of carboxymethylated lignin and its application as a dispersant. European Polymer Journal. 70, 371-383, 2015.

LI, H. Y.; Sun, S. N.; Wang, C. Z.; Sun, R. C. Structural and dynamic changes of lignin in Eucalyptus cell walls during successive alkaline ethanol treatments. Industrial Crops and Products. 74,200-208, 2015.

LOPES, A. M. C.; João, K. G.; Rubik, D.; Bogel-Lukasik, E.; Andreaus, J.; Duarte, L.C.; BogelLukasik, R. Pretreatment of lignocellulosic biomass using ionic liquids: Wheat straw fractionation. Bioresource Technology. 142, 198-208, 2013.

MOHAN, K.; Kong, F.; Fatehi, P. Production of carboxymethylated lignin and its application as a dispersant. European Polymer Journal. 70, 371-383, 2015.

MOUSAVIOUN P, Halley PJ, Doherty WOS. Thermophysical properties and rheology of PHB /lignin blends. Ind Crop Prod 50:270 - 275, 2013.

REIS, C. L. B.; Silva, L. M. A.; Rodrigues, T. H. S.; Félix, A. K. N.; Santiago-Aguiar, R. S.; Canuto, K. M.; Rocha, M. V. P. Pretreatment of cashew apple bagasse using protic ionic liquids: Enhanced enzymatic hydrolysis. Bioresource Technol. 224, 694-701, 2017.

ROCHA, M. V.P., Rodrigues, T. H. S., Macedo, G.R. Gonçalves, L. R. B. Enzymatic Hydrolysis and Fermentation of Pretreated Cashew Apple Bagasse with Alkali and Diluted Sulfuric Acid for Bioethanol Production. Appl. Biotechnol, v. 155, p.407-417, 2009.

ROCHA, M.V.P. T.H.S. Rodrigues, V.M.M. Melo, L.R.B. Gonçalves, G.R.De. Macedo. Cashew apple bagasse as a source of sugars for ethanol production by Kluyveromyces marxianus CE025 J. Ind. Microbiol. Biotechnol., 38, pp. 1099-1107, 2011.

ROCHA, M.V.P. T.H.S. Rodrigues, T.L. de Albuquerque, L.R.B. Gonçalves, G.R. de Macedo. Evaluation of dilute acid pretreatment on cashew apple bagasse for ethanol and xylitol production Chem. Eng. J., 243, pp. 234-243, 2014.

SILVA, C. G.; Grelier, S.; Pichavant, F.; Frollini, E.; Castellan, A. Adding value to lignins isolated from sugarcane bagasse and Miscanthus. Industrial Crops and Products, v.42, p. 87- 95, 2013. 